\title{
Transaction
}

\section{Successive Saccharification and Fermentation of Cellulosic Agricultural Residues Using a Combination of Cellulase and Recombinant Yeast}

\author{
Xuzhe Zhao ${ }^{* 1}$, Xianxiang Liang ${ }^{* 1}$, Shuqin Han ${ }^{* 1}$, Toshiyuki Uryu ${ }^{* 1}$, and Takashi Yoshida ${ }^{* 1, * 2, *}$ \\ ${ }^{* 1}$ Department of Bio and Environmental Chemistry, Kitami Institute of Technology, \\ 165 Koen-cho, Kitami 090-8507, Hokkaido, Japan \\ ${ }^{*}$ Research Center for Environmentally Friendly Materials Engineering, \\ Muroran Institute of Technology, 27-1 Mizumoto-cho, Muroran 050-8585, Hokkaido, Japan
}

\begin{abstract}
Bioethanol was produced from agricultural residues in Hokkaido Prefecture, Japan, by dilute alkali pretreatment, and then successive saccharification with cellulase and fermentation with recombinant yeast pYBGA1 that is a recombinant laboratory yeast expressing $\beta$-glucosidase. The agricultural residues, beet pulp, beet leaf, corn stover, and weed were pretreated with $2 \% \mathrm{NaOH}$ aqueous solution for $1 \mathrm{~h}$ at $121{ }^{\circ} \mathrm{C}$ to remove lignin. The pretreated beet pulp $(20 \mathrm{~g} / \mathrm{L})$, for example, was then saccharified for $24 \mathrm{~h}$ by Cellic CTec (10 wt $\%$ to beet pulp) as the cellulase at $50^{\circ} \mathrm{C}$ to give glucose $(11.8 \mathrm{~g} / \mathrm{L})$ at relatively good rates. After the temperature decreased to $30^{\circ} \mathrm{C}$, the resulting glucose was continuously fermented for $36 \mathrm{~h}$ by addition of $1 \times 10^{8}$ cells $/ \mathrm{mL}$ of pYBGA1 yeast to give $5.54 \mathrm{~g} / \mathrm{L}$ of bioethanol in $60 \%$ and $92 \%$ theoretical yields of cellulose in beet pulp and glucose saccharified, respectively. Other agricultural residues also afforded bioethanol by the successive saccharification and fermentation. It was found that the appropriate cellulase for saccharification differed with the kind of agricultural residue ; beet pulp was effectively saccharified by Cellic CTec, beet leaf and corn stover by Sucrose C, and weed by Sumizyme C. These agricultural residues were found to be suitable for the production of bioethanol because Hokkaido Prefecture is the most abundant producer of beets and corn in Japan, and accordingly, agricultural residues are easily available. pYBGA1 was also found to be a good yeast for the fermentation of sugars saccharified from agricultural residues.
\end{abstract}

Keywords: Agricultural residue, Hokkaido Prefecture, Cellulases, pYBGA1 yeast, Successive saccharification and fermentation, Bioethanol

(Received 13 April, 2014 ; Accepted 21 May, 2014)

\section{Introduction}

Bioethanol produced from renewable plant resources is expected to provide an environment-friendly and clean energy to replace fossil fuels. The raw materials currently used for the industrial process are mainly starches of grains and corn, which are foods. However, cellulosic bioethanol from non-food plants is becoming increasingly attractive because of the great abundance of cellulose produced by plants on earth [1]. Although both starch and cellulose are composed of glucose, unlike starchy biomasses, native cellulose is highly resistant to enzymatic saccharification because it has crystalline regions in the molecule that are present as a lignincellulose complex. Lignin inhibits enzymatic saccharification and fermentation. Therefore, pretreatment is needed to relax the highly crystalline

\# corresponding author structure and to remove lignin. Although the crystalline region was completely hydrolyzed to glucose by concentrated sulfuric acid [2], a large amount of toxic sulfuric acid is required and it is difficult to recover. Therefore, industrial saccharification of cellulosic raw materials to glucose is accomplished by use of dilute sulfuric acid, followed by fermentation with yeast [3,4].

Several investigations of the production of bioethanol from cellulosic raw materials have been reported. Microorganisms appropriate for cellulase production and experimental conditions for saccharification were also reported. Among them, Panicum virgatum, commonly known as switchgrass, was pretreated by soaking in ammonium hydroxide (30\%) at $15^{\circ} \mathrm{C}$ to $30^{\circ} \mathrm{C}$ in pilot scale bioreactors. Simultaneous saccharification and fermentation of the pretreated switchgrass with Saccharomyces cerevisiae gave $73 \%$ of the theoretical yield bioethanol in the $50 \mathrm{~L}$ reactor and $52-74 \%$ in the $350 \mathrm{~L}$ reactor [5]. An alkali pretreated rice 
straw was saccharified by a microorganism to give glucose as a main component in the hydrolyzates, suggesting that Tricoderma ZM4-F3 is an effective and useful fungus for cellulase production [6]. Corn stover was used as a substrate for enzymatic saccharification by a cellulase produced from Penicillium funiculosum. The conversion of hemicellulose and cellulose in corn stover pretreated with dilute $\mathrm{NaOH}$ was more than $80 \%$ after $24 \mathrm{~h}$ of saccharification when using a $5 \mathrm{~g} / \mathrm{L}$ initial concentration with 80 units $/ \mathrm{mL}$ of the enzyme, respectively $[7,8,9]$. Extracellular enzymes produced by Phanerochaete chrysosporium degraded lignin in corn fiber and saccharified it, and the subsequent simultaneous saccharification and fermentation of the hydrolysates using Saccharomyces cerevisiae enhanced bioethanol production [10]. The sugar composition and enzymatic saccharification of fractionated beet pulp, which is a residue after extraction of sugar from beets, were carried out to investigate microorganisms having cellulase, and indicated that Aspergillus niger enzyme produced much higher saccharification of beet pulp [11].

Previously, we reported a two-step acid hydrolysis of tissue paper, cotton, and sawdust, with the result that whole celluloses including the crystalline region were hydrolyzed to obtain a mixture of glucose and cellooligosaccharides; that is, these cellulosic materials were partially hydrolyzed by concentrated sulfuric acid $(80 \mathrm{wt} \%)$ in the first step, and then the hydrolysis was continued in the second step with hot sulfuric acid that was diluted with water. The hydrolyzates from tissue paper, cotton, and sawdust were fermented with recombinant pYBGA1 yeast converting $\beta$-glucosidase into ethanol in good yields $[12,13]$. We also reported that ethanol was produced at good rates by direct saccharification and fermentation of cellooligosaccharides with pYBGA1 yeast. For example, cellobiose in the concentration of $50 \mathrm{~g} / \mathrm{L}$ was directly fermented for $60 \mathrm{~h}$ with $1 \times 10^{8}$ cells $/ \mathrm{ml}$ of $\mathrm{pYBGA} 1$ yeast at $30^{\circ} \mathrm{C}$ to give ethanol at an $80 \%$ theoretical conversion rate and a concentration of more than $20 \mathrm{~g} / \mathrm{L}$ [14]. These results suggest that pYBGA1 yeast has some advantages as a simple procedure for effective fermentation of glucose and cello-oligosaccharides and for reducing time, cost, and energy consumptions [14].

Cellulosic agricultural residues are suitable raw materials for the production of bioethanol in local areas because they are wastes, not foods, and bioethanol, especially, is an ideal energy source for local production and local consumption. Hokkaido Prefecture is in the northern part of Japan, and agriculture is one of its important industries [15]. Among the locally available agricultural products, beets and corn are the most abundant in Hokkaido Prefecture. The recent 5-year average of the productions was $3663 \mathrm{kt}$ and $111 \mathrm{kt}$ for beets and corn, respectively [16,17]. Therefore, these agricultural residues are promising raw materials for the production of bioethanol while protecting the environment, but effective application of agricultural residues has not been achieved yet.

In this paper, we report the saccharification of cellulosic agricultural residues by several cellulase enzymes, followed by fermentation of the resulting glucose by recombinant pYBGA1 yeast. A combination of cellulase and pYBGA1 yeast was also investigated with each agricultural residue.

\section{Materials and Methods}

\subsection{Materials}

Beet pulp was supplied by a local company, Hokkaido Togyo Co. Ltd., Hokkaido, Japan. Beet leaf and corn stover were provided by a local farm in Kitami City, Hokkaido. Weeds were obtained from the lawn of our university. These agricultural residues were washed several times with water and then dried in an oven at $40^{\circ} \mathrm{C}$. Thereafter, the residues were shredded and ground to a powder by an absolute mill. The powdered raw materials were stored in sealed glass bottles at low temperature in a desiccator for further use. pYBGA1 yeast was kindly supplied by the National Research Institute of Brewing and was pre-incubated on agarose medium with cellobiose as a carbon source according to the procedure described in our previous paper [14]. The pYBGA1 yeast cells were counted using a cell counter. Cellulases used in this work, Cellic CTec (Novozymes Japan Ltd., 1000 EGU/g), Sucrase C (Mitsubishi-Kagaku Foods Corp., 3000 U/g), Sumizyme C (Shin Nihon Chemical Co.,Ltd., 1500 U/g), Meicelase (Meiji Seika Pharma Co.,Ltd., 400 FPU/g), Sumizyme AC (Shin Nihon Chemical Co.,Ltd., 2000 U/g), GODO-TCL (Oenon Holdings, Inc., $100 \mathrm{FPU} / \mathrm{g}$ ), and "Onozuka"RS (Yakult Honsha Co.,Ltd., $20000 \mathrm{U} / \mathrm{g}$ ) were obtained from the respective companies. Yeast extract and peptone were purchased from Merck Chemicals, Japan, and Kyokuto Pharmaceutical Industrial Co. Ltd., Japan, respectively.

\subsection{Measurement}

Thermogravimetric analysis (TGA) was conducted with a Shimadzu DTG-60 thermoanalyzer during heating at $10^{\circ} \mathrm{C} / \mathrm{min}$ under a nitrogen atmosphere. Saccharified sugars were measured quantitatively at $40^{\circ} \mathrm{C}$ by a reverse- 
phase HPLC system with a Tosoh TSK-gel amide-80 column $(5 \mu \mathrm{m}, 4.6 \mathrm{~mm} \times 250 \mathrm{~mm})$ eluted with a $1: 1$ acetonitrile and water solution at a flow rate of $0.5 \mathrm{~mL} /$ min with a Tosoh RI detector using glucose as a standard in the calibration curve. The concentration of ethanol produced was determined under a nitrogen atmosphere by a Shimadzu GC-8A gas chromatograph with a Shimadzu capillary column $(\mathrm{SE}-30,3.2 \mathrm{~mm} \times 30 \mathrm{~m})$ and a hydrogen flame ionization detector. The column and injection temperatures were $60^{\circ} \mathrm{C}$ and $130^{\circ} \mathrm{C}$, respectively.

\subsection{Component analysis of agricultural residues}

The content of water and ash in dried agricultural residues used here was performed by the TGA as shown in Figure 1. The concentrations of cellulose, hemicellulose, and lignin in the powdered agricultural residues before and after alkaline pretreatment were determined according to the modified method of the National Renewable Energy Laboratory (NREL), USA [18].

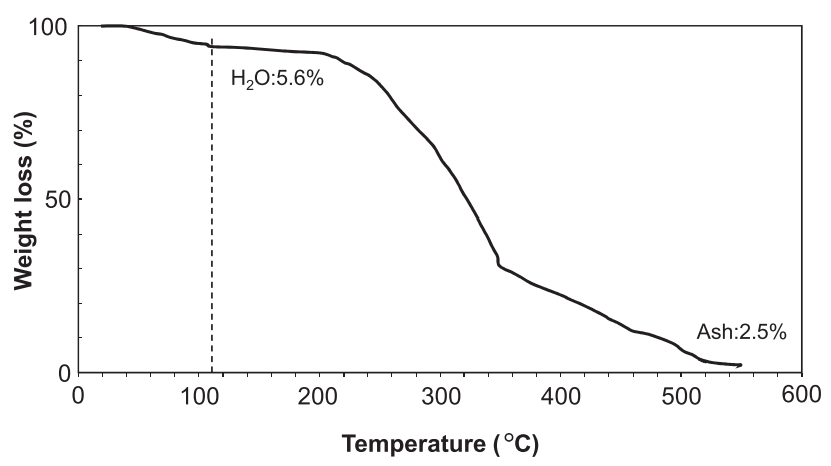

Fig. 1 Thermogravimetric analysis of dried beet pulp on the first heating run $\left(10{ }^{\circ} \mathrm{C} / \mathrm{min}\right)$ under $\mathrm{N}_{2}$. The heating was kept for $10 \mathrm{~min}$ at $110^{\circ} \mathrm{C}$.

\subsection{Dilute alkali pretreatment of agricultural residues}

A typical procedure for the pretreatment of the agricultural residues with dilute alkali solution was as follows. The dried and powdered beet pulp (5.0 g) was treated with $2 \%$ aqueous $\mathrm{NaOH}(50 \mathrm{~mL})$ for $1 \mathrm{~h}$ at $121^{\circ} \mathrm{C}$ in an autoclave. The pretreatment was carried out at $121^{\circ} \mathrm{C}$ in this work because the higher temperature gave by-products by an excessive degradation of cellulose and hemicellulose [19,20]. The residues were collected by centrifugation and then washed several times with water to neutral $\mathrm{pH}$. The resulting beet pulp was dried in the oven at $50^{\circ} \mathrm{C}$ under vacuum to give $2.2 \mathrm{~g}$ of alkali treated beet pulp. Other agricultural residues ( $5.0 \mathrm{~g}$ each sample), beet leaf, corn stover, and weed, were also pretreated by the same procedure as above to give 2.1-2.3 $\mathrm{g}$ of pretreated residues, respectively.

\subsection{Successive saccharification and fermentation of alkali-pretreated agricultural residues}

A typical procedure for the successive saccharification and fermentation of alkali- pretreated agricultural residues is as follows. In a $300 \mathrm{~mL}$ Erlenmeyer flask, $100 \mathrm{~mL}$ of deionized water was added to $2.0 \mathrm{~g}$ of the alkali-pretreated powdered beet pulp. The $\mathrm{pH}$ of the solution was adjusted to 4.5 by dilute aqueous $\mathrm{HCl}$, and then Cellic CTec (10 wt $\%$ of beet pulp) was added. The flask was sealed with a sponge stopper and the mixture was incubated in an oven for $24 \mathrm{~h}$ at $45^{\circ} \mathrm{C}$ using gentle stirring by a rotary shaker. After lowering the temperature of the saccharified mixture to $30^{\circ} \mathrm{C}, 10 \mathrm{~g} / \mathrm{L}$ of yeast extract and $20 \mathrm{~g} / \mathrm{L}$ of peptone were added. The $\mathrm{pH}$ of the solution was adjusted to 5.0 with dilute aqueous $\mathrm{NaOH}$ and then pYBGA1 yeast $\left(1 \times 10^{8}\right.$ cells $\left./ \mathrm{mL}\right)$ was added to the saccharified solution. The fermentation was continued at $30^{\circ} \mathrm{C}$ for further $36 \mathrm{~h}$ in an oven with gentle stirring using a rotary shaker. The saccharified glucose and fermented ethanol was sampled using a syringe with a long needle every $6 \mathrm{~h}$ to measure the concentration of the products.

\section{Results and Discussion}

\subsection{Alkali-pretreatment of agricultural residues}

Table 1 shows the results of pretreatment of dried and powdered agricultural residues used in this work with $2 \%$ aqueous $\mathrm{NaOH}$ solution for $1 \mathrm{~h}$ at $121^{\circ} \mathrm{C}$ in the autoclave. Dilute acid pretreatment was also reported, but, toxic furfural derivatives were produced as a by-product $[2,3,13]$. Therefore, we used a dilute alkali for the pretreatment to remove lignin, which inhibits enzymatic saccharification, followed by fermentation. As shown in Table 1, the concentrations of cellulose and hemicellulose of beet pulp increased and decreased, respectively, to $74.0 \mathrm{wt} \%$ and $10.9 \mathrm{wt} \%$ from $58.3 \mathrm{wt} \%$ and $16.7 \mathrm{wt} \%$. The lignin concentration decreased to below one third.

Table 1 Component of agricultural residues in Hokkaido prefecture, Japan, before and after alkaline pretreatment ${ }^{\mathrm{a}}$.

\begin{tabular}{|c|c|c|c|c|c|c|c|c|}
\hline & \multicolumn{2}{|c|}{ Beet pulp } & \multicolumn{2}{|c|}{ Beet leaf } & \multicolumn{2}{|c|}{ Corn stover } & \multicolumn{2}{|c|}{ Weed } \\
\hline & $\begin{array}{l}\text { Before } \\
\text { wt } \%\end{array}$ & $\begin{array}{l}\text { After } \\
\text { wt } \%\end{array}$ & $\begin{array}{c}\text { Before } \\
\text { wt } \%\end{array}$ & $\begin{array}{l}\text { After } \\
\text { wt } \%\end{array}$ & $\begin{array}{c}\text { Before } \\
\text { wt } \%\end{array}$ & $\begin{array}{l}\text { After } \\
\text { wt } \%\end{array}$ & $\begin{array}{c}\text { Before } \\
\text { wt } \%\end{array}$ & $\begin{array}{l}\text { After } \\
\text { wt } \%\end{array}$ \\
\hline Cellulose & 58.3 & 74.0 & 36.6 & 61.5 & 46.2 & 66.4 & 44.5 & 53.6 \\
\hline Hemicellulose & 16.7 & 10.9 & 23.3 & 13.2 & 28.0 & 19.5 & 30.8 & 28.3 \\
\hline Lignin & 4.2 & 1.2 & 9.4 & 2.2 & 10.6 & 2.8 & 11.2 & 7.8 \\
\hline Water & 5.6 & 6.5 & 10.1 & 11.3 & 5.4 & 5.8 & 5.2 & 6.3 \\
\hline Ash & 2.5 & 2.2 & 18.0 & 11.5 & 6.5 & 4.8 & 6.2 & 3.7 \\
\hline Others & 12.7 & 5.2 & 2.6 & 0.3 & 3.3 & 0.7 & 2.1 & 0.3 \\
\hline
\end{tabular}

a) Alkaline pretreatment was carried out with $5 \mathrm{~g}$ of each agricultural residue in $2 \% \mathrm{NaOH}$ aqueous solution for $1 \mathrm{~h}$ at $121^{\circ} \mathrm{C}$ in an autoclave. Pretreated agricultural residues $(2.1 \sim 2.3 \mathrm{~g})$ were obtained. 
was converted to ethanol at the rates of around $90 \%$. The pYBGA1 yeast also has a high ability to directly ferment cello-oligosaccharides to ethanol [12,14]. pYBGA1 itself produced $\beta$-glucosidase on the cell wall, and cellooligosaccharides are hydrolyzed into glucose, followed by fermentation into ethanol. Therefore, ethanol was directly obtained from cello-oligosaccharides that were saccharified from cellulose by exo-type cellulases. Among the cellulase complexes used in this work, cellulases, including the exo-type cellulases Sumizyme C and Meicelase, should saccharify beet pulp to glucose and cello-oligosaccharides, which were fermented with pYBGA1 to give ethanol. On the other hand, because Cellic CTec is also a complex type cellulase, glucose is the only sugar saccharified with $\beta$-glucosidase. Therefore, pYBGA1 fermented the glucose to give ethanol.

Table 3 summarizes the successive saccharification and fermentation of agricultural residues under the optimal conditions. Agricultural residues at $20 \mathrm{~g} / \mathrm{L}$ and cellulase at $10 \mathrm{wt} \%$ or $15 \mathrm{wt} \%$ of the feed were used. As shown in Table 2, several cellulases were tested to determine the optimal saccharification condition. For beet leaf and corn stover, Sucrase C was the most effective cellulase for saccharification and produced glucose at 9.4 and $7.1 \mathrm{~g} / \mathrm{L}$, respectively, at $60 \%$ and $43 \%$ conversions based on the cellulose concentration for $24 \mathrm{~h}$ saccharification. Weed was saccharified with Sumizyme $\mathrm{C}$ to give $6.1 \mathrm{~g} / \mathrm{L}$ of glucose at $51 \%$ conversion. Thus, the most appropriate cellulase for the saccharification depended on the kind of agricultural residue. As shown in Table 1, although the cellulose concentration in weed was lower than that of other agricultural residues, it was considered a convenient raw material because of the abundance of plant waste in general. The fermentation shown in Table 3 was also carried out successively with pYBGA1 yeast for $48 \mathrm{~h}$ at $30^{\circ} \mathrm{C}$ and $\mathrm{pH}$ 5.0. Ethanol was obtained at good conversion rates based on sugars in each saccharified agricultural residue.

\section{Conclusion}

As described above, cellulose in agricultural residues was mainly converted to ethanol ; that is, the successive saccharification and fermentation of agricultural residues were carried out by a combination of cellulase for saccharification and pYBGA1 yeast for fermentation under the optimal conditions to give ethanol at good conversion rates. We tested several cellulases for saccharification of the agricultural residues. Among them, Cellic CTec was the most effective for beet pulp, Sucrase $\mathrm{C}$ for beet leaf and corn stover, and Sumizyme C for weed, respectively, for the $24 \mathrm{~h}$ saccharification. When beet pulp was saccharified with Cellic CTec for $24 \mathrm{~h}$ at $\mathrm{pH} 4.5$ and $45^{\circ} \mathrm{C}, 11.8 \mathrm{~g} / \mathrm{L}$ of glucose was obtained in $72 \%$ conversion based on the cellulose concentration of the alkali-pretreated beet pulp. The fermentation was successively performed by adding pYBGA1 yeast for further $36 \mathrm{~h}$ at $30^{\circ} \mathrm{C}$ and $\mathrm{pH} 5.0$ to produce $5.54 \mathrm{~g} / \mathrm{L}$ of ethanol at $60 \%$ and $92 \%$ conversions of cellulose content in beet pulp and of the glucose saccharified, respectively. Other agricultural residues, beet leaf, corn stover, and weed, gave ethanol at 91 and $96 \%$ conversions, respectively, in each optimal condition. However, based on the cellulose concentration, the conversion to ethanol decreased slightly, probably because of incomplete saccharification of cellulose having crystalline moiety. In this work, we mainly investigated successive saccharification and fermentation of glucose saccharified from cellulose in the agricultural residues in Hokkaido Prefecture. Bioethanol production fermented by cellooligosaccharides and pentoses from cellulose and hemicellulose in agricultural residues will be further investigated to find the best combination of cellulase, hemicellulase, and yeast for good conversion rates.

\section{Acknowledgements}

We gratefully acknowledge Drs. K. Iwashita and H.

Table 3 Successive saccharification and fermentation of agricultural residues under optimal condition ${ }^{\mathrm{a}}$.

\begin{tabular}{|c|c|c|c|c|c|c|c|c|c|c|}
\hline \multicolumn{7}{|c|}{ Saccharification ${ }^{b}$} & \multicolumn{4}{|c|}{ Fermentation $b$} \\
\hline \multirow[t]{2}{*}{ Sample } & \multirow[t]{2}{*}{ Cellulase } & \multirow[b]{2}{*}{ wt $\%$} & \multirow{2}{*}{$\begin{array}{l}\text { Temp } \\
{ }^{\circ} \mathrm{C}\end{array}$} & \multirow[t]{2}{*}{$\mathrm{pH}$} & \multirow{2}{*}{$\begin{array}{c}\text { Glucose } \\
\text { g/L }\end{array}$} & \multirow{2}{*}{$\begin{array}{c}\text { Conversion } \\
\%\end{array}$} & \multirow{2}{*}{$\begin{array}{c}\text { pYBGA1 } \\
\times 10^{8} \mathrm{cell} / \mathrm{ml}\end{array}$} & \multicolumn{2}{|c|}{ Ethanolc } & \multirow[b]{2}{*}{$\%^{\mathrm{e}}$} \\
\hline & & & & & & & & $\mathrm{g} / \mathrm{L}$ & $\%^{d}$ & \\
\hline Beet pulp & Cellic CTec & 10 & 45 & 4.5 & 11.8 & 72 & 1 & 5.54 & 66 & 92 \\
\hline Beet leaf & Sucrase C & 10 & 45 & 5.0 & 9.4 & 69 & 1 & 4.39 & 63 & 91 \\
\hline Corn stover & Sucrase C & 10 & 45 & 5.0 & 7.1 & 48 & 1 & 3.32 & 44 & 91 \\
\hline Weed & Sumizyme C & 15 & 55 & 4.5 & 6.1 & 51 & 1 & 3.00 & 49 & 96 \\
\hline
\end{tabular}

a) Dry beet pulp $(2 \mathrm{~g})$ in water $(100 \mathrm{ml})$ was used.

b) The saccharification was performed for $24 \mathrm{~h}$ and then fermentation was started by using pYBGA1 yeast for further $48 \mathrm{~h}$ at $30^{\circ} \mathrm{C}$ and $\mathrm{pH} 5.0$ after addition of yeast extract and peptone.

c) The concentration of glucose and ethanol was determined by HPLC and GC, respectively.

d) Based on cellulose content of alkaline-pretreated agricultural residues.

e) Based on glucose saccharified. 
Iefuji of the National Research Institute of Brewing for providing pYBGA1 yeast. We are grateful for support in part by a Grant-in-Aid for Scientific Research from the Japan Society for the Promotion of Science 2008-2010 (No. 20550116) and the SVBL research program of the Kitami Institute of Technology 2009-2011.

\section{References}

1. C. E. Wyman, Ed, Handbook of bioethanol. Taylor \& Francis, Washington DC (1996).

2. Y. Sun, and J. Cheng, "Hydrolysis of lignocellulosic materials for ethanol production: a review", Bioresour. Technol., 83, 1-11 (2002).

3. M. Su, W. Tzeng, and Y. Shyu, "Dilute acid pretreatment and enzymatic saccharification of sugarcane tops for bioethanol production", Bioresource. Technol., 102, 10915-10921 (2011).

4. Y. Sun, and J. J. Cheng, "Dilute acid pretreatment of rye straw and bermudagrass for ethanol production", Bioresour. Technol ., 96, 1599 - 1606 (2005).

5. A. Isei, J. N. Himmelsbach, J. Strohl, A. L. Pometto III, D. R. Raman, and R. P. Anex, "Pilot scale fermentation of aqueous ammonia soaked switchgrass", Appl. Biochem. Biotechnol., 157, 453462 (2009).

6. M. Jeya, Y. Zhang, I. Kim, and J. Lee, "Enhanced saccharification of alkali-treated rice straw by cellulase from Trametes hirsute and statistical optimization of hydrolysis conditions by RSM", Bioresour. Technol., 100, 1285-1290 (2008).

7. A. M. Elshafei, J. L. Vega, K. T. Klasson, E. Clausen, and J. L. Gaddy, "The saccharification of corn stover by cellulase from Penicillium funiculosum", Bioresour. Technol., 35, 73-80 (1991).

8. J. Zhao, and L. Xia, "Simultaneous saccharification and fermentation of alkaline-pretreated corn stover to ethanol using a recombinant yeast strain", Fuel process Technol., 90, 1193-1197 (2009).

9. J. Zhao, and L. Xia, "Bioconversion of corn stover hydrolysate to ethanol by a recombinant yeast strain", Fuel Process Technol., 91, 1807-1811 (2010).

10. P. Shrestha, M. Rasmussen, S. K. Khanal, A. L. Pometto III, and J. H. Leeuwen, "Solid-substrate fermentation of corn fibre by Phanerochaete chrysosporium and subsequent fermentation of hydrolysate into ethanol", J. Agric. Food Chem ., 56, 3918-3924(2008).
11. M. Kobayashi, K. Funae, H. Ueyama, S. Ohya, and M. Tanaka, "Sugar composition of beet pulp polysaccharides and their enzymatic hydrolysis", Biosci. Biotech. Biochem., 57, 998-1000 (1993).

12. K. Iwashita, K. Todoroki, H. Kimura, H. Shimoi, and K. Ito, "The bgl A gene of Aspergillus kawachii encodes both extracellular and cell wall-bound $\beta$ glucosidases", Biosci. Biotechnol. Biochem., 62, 1938 - 1946 (1998).

13. T. Uryu, M. Sugie, S. Ishida, S. Konoma, H. Kato, K. Katsuraya, K. Okuyama, G. Borjihan, K. Iwashita, and H. Iefuji, "Chemo-enzymatic production of fuel ethanol from cellulosic materials utilizing yeast expressing $\beta$-glucosidases", Appl. Biochem. Biotechnol. 135, 15 - 31 (2006).

14. X. Liang, T. Yoshida, and T. Uryu, "Direct saccharification and ethanol fermentation of cellooligosaccharides with recombinant yeast", Carbohrdr. Polym., 91, 157-161(2013).

15. M. Wada, "Japanese Regional Development Systemthe case of Hokkaido", http : //appsv.main.teikyo-u. ac.jp/tosho/keizaigaku43-2-03.pdf (2014).

16. Ministry of Agriculture, Forestry and Fisheries, http : //www. maff. go.jp/j/tokei/sihyo/index. html (2014).

17. Official statistics of Japan, http : //www.e-stat.go.jp/ SG1/estat/eStatTopPortalE.do (2014).

18. A. Sluiter, B. Hames, R. Ruiz, C. Scarlata, J. Sluiter, D. Templeton, and D. Crocker, "Determination of structural carbohydrates and lignin in biomass", National Renewable Energy Laboratory, http : // www.nrel.gov/biomass/pdfs/42618 (2009).

19. L. Kumar, Z. Tooyserkani, S. Sokhansanj, J. N. Saddler, "Does densification influence the steam pretreatment and enzymatic hydrolysis of softwoods to sugars?", Bioresour. Technol., 121, 190-198 (2012)

20. Y. Yu, Y. Feng, C. Xu, J. Liu, D. Li, “Onsite biodetoxification of steam-exploded corn stover for cellulosic ethanol production", Bioresour. Technol., 102, 5123-5128 (2011).

21. National Institute of Technology and Evaluation, http : //www.bio.nite.go.jp/ngac/e/sc1-e.html (2014).

22. X. Liang, T. Yoshida, and T. Uryu, "Bioethanol production from mercerized cellulose by cellulase enzymatic saccharification and recombinant yeast fermentation", Proceedings of the 13th Pacific Polymer Conference, Poster-S8-006 (Kaohsiung, Taiwan) (2013). 